\title{
The skull of Stephanorhinus kirchbergensis (Jäger, 1839) (Mammalia, Rhinocerotidae) from Irkutsk Province, Eastern Siberia
}

\author{
Emmanuel M. E. Billia
}

\begin{abstract}
The famous skull discovered in the Irkutsk Province (Eastern Siberia), previously attributed to "Rhinoceros Merckii" [=Stephanorhinus kirchbergensis] both by Chersky (1874) and by Brandt (1877), preserved in the collections of the Zoological Institute of the Russian Academy of Science in St. Petersburg, is described. It represents one of the five skulls ascribed to this taxon discovered until now in Eurasia and the only one coming from the Russian territory. A brief history of the $S$. kirchbergensis and some notes on three other three skulls attributed to the same species are also included. Unlike the woolly rhinoceros Coelodonta antiquitatis and other Plio-Pleistocene rhinoceroses, which abound in the Eurasian continent, $S$. kirchbergensis seems to be rare on this wide territory. This is one of the two records of this species from Eastern Siberia, and one of the very few from Russia.
\end{abstract}

KEY-WORDS: Rhinoceros, Irkutsk Province, Plio-Pleistocene.

Emmanuel M. E. Billia [e.billia@libero.it], via Bacchiglione 3, Roma 00199, Italy.

\section{Череп Stephanorhinus kirchbergensis (Jäger, 1839) (Mammalia, Rhinocerotidae) из Иркутской области, Восточная Сибирь}

\author{
Эммануил М. Е. Биллиа
}

\begin{abstract}
РЕЗЮМЕ. Описывается известный череп носорога, найденный в Иркутской области и прежде отнесенный к "Rhinoceros Merckii" [=Stephanorhinus kirchbergensis] Черским (1874) и Брандтом (1877), хранящийся в коллекции Зоологического института Российской Академии наук в СанктПетербурге. Это один из пяти известных для этого вида черепов и единственный, найденный на территории России. В статье также кратко рассматривается история вида S. kirchbergensis и даются замечания о трех других черепах, отнесенных к этому виду. В отличие от шерстистого носорога, Coelodonta antiquitatis и других плио-плейстоценовых носорогов, обычных в Евразии, S. kirchbergensis был довольно редок на этой обширной территории. Находка в Иркутской области является всего лишь второй для Восточной Сибири и одной из немногих для всей России.
\end{abstract}

КЛЮЧЕВЫЕ СЛОВА: Rhinoceros, Иркутская область, плио-плейстоцен.

\section{Introduction}

The ZIN 10718 skull comes from an unknown locality in the Irkutsk Province and it is ascribed to Stephanorhinus kirchbergensis (Jäger, 1839) [=Rhinoceros mercki Jäger, 1839; =Dicerorhinus mercki (Jäger, 1839); =Dicerorhinus kirchbergensis (Jäger, 1839)], better known in Russia as "nosorog Merka" (literally, Merck's rhinoceros). Previously preliminarily described both by Chersky (1874) and by Brandt (1877) as "Rhinoceros Merckii Jaeger, 1839" [sic], even if without mandible and dentition, it represents the only skull coming from the Russian territory and is one of the five skulls assigned to this species from the whole of Eurasia. At first, it was placed in the collections ( $\mathrm{N}$ 26) of the Irkutsk Regional Ethnographic museum. Later, for a long time, is has not been traceable. Recently, it has been found in the collection of the Zoological Institute of the Russian Academy of Science (abbreviated ZIN), provided with the wrong label ZIN 10817.
In European literature, this skull is quite rarely mentioned. Schroeder (1903), Azzaroli (1962a), Loose (1975), and Guérin (1980) apart, none of the other specialists referred to this specimen. It is also interesting to note that Chersky's name is never cited anywhere. Illustrations of the Irkutsk skull are given in Chersky (1874), in Brandt (1877: pl. 1-2, figs. 1-3), in Schroeder (1903: pl. 2, fig. 1 and pl. 3, fig. 2) who compared this skull with two other skulls, that from Daxlanden (see below) and another one from Ilford (Essex) ascribed by Woodward (1874) to Rhinoceros leptorhinus Owen [=Rhinoceros hemitoechus Falconer, 1868; =Dicerorhinus hemitoechus (Falconer, 1868); =Stephanorhinus hemitoechus (Falconer, 1868)]. According to Loose (1975: 20), the skull from Irkutsk belongs to D. hemitoechus. Guérin, who, like other European specialists, had never seen the skull from Irkutsk, considered it as D. mercki (Guérin, 1980: 628, 631).

Actually, there are some complex problems which involved heated debates regarding the skull from Irkutsk, 
as well as some other skulls, the attribution of which has been - and still is - decidedly controversial. Though subject of several systematic studies since some time, yet, so far, no agreement has been reached by palaeontologists as to their systematic positions. In my opinion, there is sufficient motive to briefly discuss here the situation concerning at least three well-known skulls: from Daxlanden, Mosbach, and Steinheim an der Murr (all the localities are in Germany).

\section{Daxlanden skull}

Found in 1802, the uncommonly well preserved skull from Daxlanden (Karlsruhe) is housed in the Landesmuseum für Naturkunde, Karlsruhe (Op/650). During the past two centuries it was variously attributed to Rh. Merckii by Meyer (1863-1864), Rhinoceros etruscus Falconer by Lartet (1867: 180-181), Rh. Mercki (Merckii) var. brachycephala by Schroeder (1903, 1930), Rh. hemitoechus Falconer by Toula (1907), Rh. merckii Jaeger by Wüst (1922), D. mercki Jaeger by Staesche (1941), D. mercki (kirchbergensis) (Jaeger) var. brachycephalus Schroeder by Mayer (1971), and eventually to $D$. kirchbergensis Jaeger by Loose (1975). Azzaroli (1962b) was uncertain about the systematic position of the Daxlanden skull, but he recognized in it some affinities with $S$. kirchbergensis. Finally, Guérin (1980: 623, 628) mistakenly erected, for this skull, the subspecies Dicerorhinus etruscus brachycephalus [=Stephanorhinus hundsheimensis (Toula, 1902); =Rhinoceros etruscus heidelbergensis (Freudenberg, 1914); =Dicerorhinus hemitoechus intermedius (Cigala-Fulgosi, 1976)]. Good illustrations of the Daxlanden skull may be found in Meyer (1863-1864: pls. 35-39), Schroeder (1903: pl. 2, fig.2 and pl. 3, fig.1), Mayer (1971), and Loose (1975: pl. 5, fig.1; pl. 6, fig.1; pl. 8, fig.3; pl. 10, fig.5; and pl. 13, fig.1).

\section{Mosbach skull}

The skull from Mosbach (Naturhistorisches Museum, Mainz; 1956/962), seriously damaged in the splanchnocranium, has been treated, among others, by Schroeder (1903, 1930), Freudenberg (1914), Wüst (1909, 1911), and Guérin (1980). Its good illustrations can be found in Loose (1975: pl. 3, fig.3, pl. 4, fig.3; pl. 8, fig.2; pl. 10, fig. 4; and pl. 13, fig.2). In his monumental work, Guérin (1980: 628) listed skulls from Mosbach, from Steinheim an der Murr, from Warsaw (Borsuk-Bialyñicka \& Jakubowski, 1972: figs.1, 2, pls. 1-4), from Taubach (Wüst, 1901: pl. 10, figs. 4-6), from Bessarabia (Azzaroli, 1962a: fig. 2-2), from Krapina (Croatia) (Gorjanovich-Kramberger, 1913: pl. 1-10-13), from Irkutsk (Brandt, 1877). Incidentally, the skull from Mosbach has not been mentioned by Fortelius et al. (1993).

\section{Steinheim an der Murr skull}

Two skulls come from Steinheim an der Murr (Staatliche Museum f. Naturkunde, Stuttgart), one iden- tified as S. hemitoechus (SMN 16938), the second-one as S. kirchbergensis (SMN 16275); both of them have been used by Staesche (1941) for his well known comparative study. The skull belonging to $S$. kirchbergensis (Staesche, 1941: pl. 11, figs. 1-3) has extensively been restored taking as a model — understandable, at least from my point of view - the one attributed to $S$. hemitoechus; evidently, any comment here seems superfluous. In any case, Guérin (1980) agreed with Staesche in considering the second skull (SMN 16275) as D. mercki. According to Fortelius et al. (1993) both skulls have to be ascribed to $S$. hemitoechus; at the same time, they widely discussed this theme ignoring the skull from Irkutsk.

\section{Description}

\section{Synonymy}

The Pleistocene "tandem-horned" Eurasian interglacial rhinoceros Stephanorhinus kirchbergensis (Jäger, 1839) has been previously identified, during the last two centuries, also as:

Rhinoceros incisivus Merck, 1784

Rhinoceros megarhinus de Christol, 1834

Rhinoceros leptorhinus Cuvier, 1836

Rhinoceros kirchbergense Jäger, 1839

Rhinoceros Merckii (or merckii, mercki, merki, Mercki) Kaup, 1841

Dicerorhinus mercki (Kaup, 1841)

Rhinoceros leptorhinus Owen, 1850

Rhinoceros (Tichorhinus) Merckii Brandt, 1877

Rhinoceros Mercki (Merckii) var. brachycephala Schroeder, 1903

Coelodonta merckii Abel, 1919

Dicerorhinus kirchbergensis Hooijer, 1947

Dicerorhinus mercki (kirchbergensis) (Jäger) var. brachycephalus Schroeder

Dicerorhinus merckii Mayer, 1971

\section{Account of Stephanorhinus kirchbergensis}

In the recent literature the Plio-Pleistocene European rhinoceroses except species of Coelodonta Bronn, 1831 and Elasmotherium Fischer von Waldheim, 1808 have traditionally been assigned to the genus Dicerorhinus Gloger, 1841. Fortelius et al. (1993) have replaced the name Dicerorhinus for all the Plio-Pleistocene European rhinoceros species by Stephanorhinus Kretzoi, 1942 as nomen conservandum, following the nomenclature previously introduced by Kretzoi (1942).

S. kirchbergensis has very often been confused with other rhinoceros species, particularly with S. hemitoechus (Falconer, 1868) and C. antiquitatis (Blumenbach, 1799). In effect, apparently, there are some similarities with these two species, at least as regards some features. Again, many authors also misidentified $S$. kirchbergensis with Stephanorhinus etruscus (Falconer, 1868), Stephanorhinus hundsheimensis (Toula, 

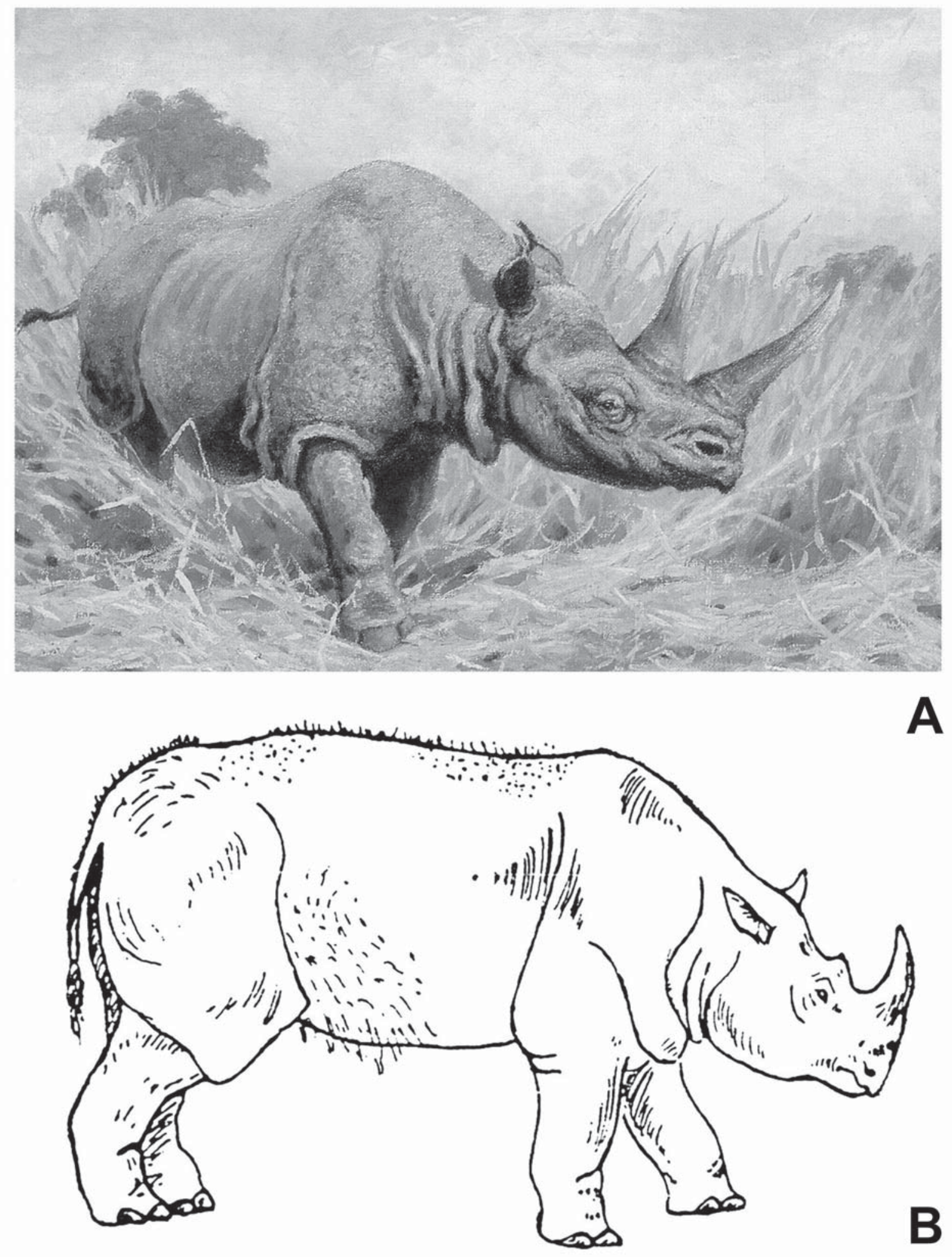
1902), Stephanorhinus jeanvireti (Guérin, 1973) [=Rhinoceros etruscus var. astensis Sacco, 1895], Stephanorhinus megarhinus (de Christol, 1834), Dicerorhinus orientalis (Schlosser, 1921), Rhinoceros binagadensis Dzhafarov 1956 and others (Billia, 2005a, b, in press ac). Besides, for a long time too many palaeontologists believed that $S$. kirchbergensis and $S$. hemitoechus represented only one species. In spite of the progress which has been made during the past decades, we must accept that many nomenclatural and taxonomical problems incontestably still exist. On the other hand, Loose (1975: 9) seized the opportunity to emphasize that "... any publications in which the name Rhinoceros (or Dicerorhinus) merckii is used, should be read with the utmost caution". Contemporary paleontologists contribute to perpetuate this depreciable "tradition" from paper to paper, from handbook to handbook. One of the basic problems, from my point of view, is represented by the fact that too often the diagnoses are exclusively based on postcranial remains so that errors of identification among the species are frequently possible, whereas the attribution by means of teeth is unequivocal, a fact that too many specialists find too difficult to accept. But, unfortunately, since "palaeontology of the mammals is mostly odontology..." (Loose, 1975: 7), it is absolutely necessary to keep in mind this ground notion, and to understand that, as a general rule, teeth are an environmental response; for this reason, they do not necessarily testify the dimensions of an animal (large teeth do not mean a large animal, but at the most a large skull) and, by the same token, when similar, they do not necessarily indicate a phylogenetic relationship between them.

My personal opinion is in favor of the wide agreement, as Heissig (1981) previously asserted, that the rhinoceroses are a highly stereotyped group with little morphological divergence; in other words, it means that, morphologically, substantial intraspecific differences and, conversely, interspecific likenesses may usually be found among them.

According to Wüst (1922), Bernsen (1927) Kurtén (1968), Guérin (1980), and other prominent paleontologists, S. kirchbergensis was depicted as a large-sized rhinoceros, in some cases absolutely gigantic ("the biggest Dicerorhinus which had ever lived on the planet") even if Loose (1975) has always vigorously rejected this thesis. However, anatomically, S. kirchbergensis has a very elongated half-high posture skull (as a browser, even if it shows also the characters of a potential grazer) with the nasal septa ossified only in its anterior portion; the mandible with long symphysis, and a high, heavy, thick horizontal ramus with a brachyodont dentition. The graviportal postcranial skeleton, undoubtedly of Stephanorhinus type, with big and long bones suggests, morphologically, a semicursorial animal. Among the several reconstructions of the species, is my opinion that of Flerov (in Flerov et al., 1955) seems to be the most realistic (Fig. 1).

The natural habitat of $S$. kirchbergensis would include a large part of the Eurasian continent, in Siberia at least up to $110^{\circ} \mathrm{E}$ longitude (Billia, 2005a, b, in press ac). The species did not inhabited British and the Mediterranean islands and the high latitudes in Siberia; where the northernmost record of the species is registered at about $64^{\circ} \mathrm{N}$ latitude (Dubrovo, 1957). The species was also recorded in the Middle East, including Lebanon and Israel (Hooijer, 1961; Bar-Yossef \& Chernov, 1972), in China (Teilhard de Chardin \& Pei, 1941; Wang, 1961; Xu, 1986; Fu, 2002), and in the Far East, in central Korea (Lee, 2001). However, the Chinese supposed records of the species may actually belong to the coexisted local species, Dicerorhinus yunchuchensis and Dicerorhinus choukoutiensis.

\section{Description of the ZIN 10718 skull from} the Irkutsk Province

A morphological description of the ZIN 10718 skull from the Irkutsk Province is given below. The skull lacks the mandible and the upper dentition.

In lateral view (Fig. 2A) the general profile shows affinities with other Pleistocene rhinoceros species; however, some distinctions may be made. The nasal is high and massive; the inclination (the distance from the rhinion and the surface of the nasal horn base) is less prominent than that in $C$. antiquitatis. In comparison with the last species, the nasal septum is open; the nasal aperture is higher and narrower, the distance from the posterior rim of the nasal aperture and the anterior rim of the orbit is shorter; the zygomatic arch appear more massive; the plane, formed by the parietal plane and the interparietal, is shorter and its inclination is less pronounced; the postglenoid and paroccipital processes show a much more massive character.

In dorsal view (Fig. 2B), in contrast with the woolly rhinoceros, the skull appears somewhat less slight; the nasal is much enlarged; the surface of the nasal horn base is wider and rather rugose, whereas that of the frontal horn is much less evident; the orbit appear massive and rather pronounced, their base is much extended. Always in contrast with Coelodonta, the zygomatic arches are more massive and noticeably enlarged outwards and then converging, almost abruptly (angle $\sim 90^{\circ}$ ), towards the temporal bones; these form a very wide oval, as a general rule wider than in Coelodonta. The occipital bone, which represents the shorter base of the trapezium formed by the facies occipitalis, shows a mild concavity (which is more evident from the occipital view) and is bent towards the inside. The two apices of the crista occipitalis are much pronounced, much more than in Coelodonta (in some skulls attributed to this species, these are even not discernable). 

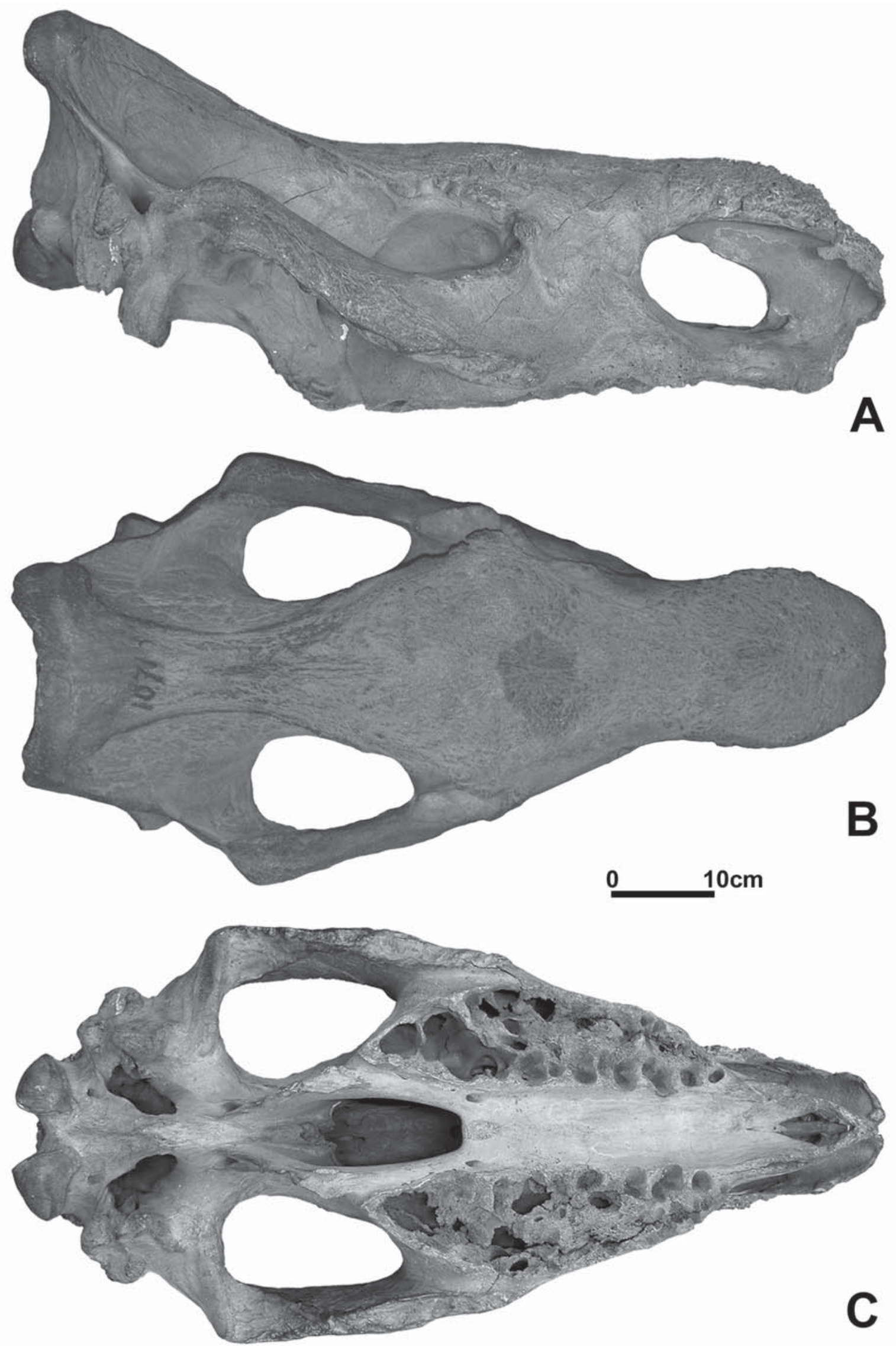
Table 1. Measurements (in mm) of ZIN 10718, the skull of Stephanorhinus kirchbergensis from the Irkutsk Province,

Eastern Siberia.

\begin{tabular}{|l|c|}
\hline maximal length occipito-nasale* & 832 \\
\hline maximal length condilus occipitalis-rhinion & 798 \\
\hline maximal length of the nasal aperture & 260 \\
\hline minimal length nasal aperture ? orbit & 135 \\
\hline $\begin{array}{l}\text { minimal transversal diameter at the postorbital } \\
\text { constriction }\end{array}$ & 119 \\
\hline length of the space occupied by the dental alveoli & 310 \\
\hline maximal width of the zygomatic arches & 390 \\
\hline minimal width of the faces occipitalis** & 204 \\
\hline medial heigth of the faces occipitalis & 251 \\
\hline $\begin{array}{l}\text { external maximal trans versal diameter of the occipital } \\
\text { condyles }\end{array}$ & 154 \\
\hline maximal transversal diameter of the foramen magnum & 49 \\
\hline maximal width of the faces occipitalis*** & 273 \\
\hline
\end{tabular}

* horizontally measured, along the sagittale plane (rhinion crista occipitalis);

** measured at the external rims of the crista occipitalis;

*** measured outwardly at the mastoid apophyses.

In ventral view (Fig. 2C) the premaxilla, laterally rounded, shows a pronounced middle concavity, even if its thickness is not remarkable; frontally, the palatal cavity ends as an "arrow tip". The dental alveoli testify a dentition of uncommon dimensions. Also from this view, the massive character of the zygomatic arches is very evident.

In occipital view the skull has a trapezium outline with the crista occipitalis represents the upper base with a mild middle concavity and very rounded angles. The large occipital crista is undoubtedly much more massive than in Coelodonta. The foramen magnum is quite round-shaped; above it, there is a very pronounced relief formed by the tuberculus nucalis.

For the measurements of ZIN 10718 see Tab. 1.

\section{Comparison}

The skull ZIN 10718 from the Irkutsk Province shows remarkable morphological affinities with the skulls from Daxlanden (LNK Op/650), from Mosbach (NMM 1956/962), and from Krapina (without number), all referred to $S$. kirchbergensis; it is particularly similar with the specimens from Mosbach and Krapina. More specifically, in lateral view the nasal is high and robust, the length and the slope of the parietal plane is very similar; besides the similar features include the open septum nasalis, the peculiar morphology of the nasal aperture, and the massive characters of the postglenoid and paroccipital processes. From the dorsal view, just as in the Daxlanden and Mosbach specimens, the Irkutsk skull appears to be less slight and much enlarged in the zygomatic arches which are strikingly massive and end abruptly at a right angle towards the temporal bones. As in the skulls from Daxlanden and from Mosbach, the nasal is very large, the orbits massive and very "chiselled" with a much pronounced anterior rim; the two rounded extremities of the occipital crest are much marked. From the ventral view it is similar in the morphology of the premaxilla and the palatal cavity, and by the conspicuous space occupied by the dental alveoli. From the occipital view, all specimens are similar in the peculiar trapezium shape, the very massive occipital crest, and the considerably pronounced tuberculus nucalis, not found in any other species. The characters mentioned above are traits suggestive of $S$. kirchbergensis.

\section{Discussion}

At present, S. kirchbergensis, unlike C. antiquitatis, which abounds in Eurasia, as well as other Plio-Pleistocene rhinoceroses, seems to be decidedly rare in that territory. Recognized as a Middle Pleistocene species in Western Europe, it is reported from few Italian, French, German, British, and East European localities only (Schroeder, 1903, 1905; Wüst, 1909, 1922; Gorjanovich-Kramberger, 1913; Staesche, 1941; Czyżewska, 1962; West et al., 1964; Borsuk-Bialyńicka \& Jakubowski, 1972; Kahlke, 1977, 1978, 1984; Guérin, 1980; Billia, 2005b, in press a-c; Billia \& Petronio, in press).

On the territory of Russia, besides the Irkutsk skull, some other remains of the $S$. kirchbergensis rhinoceros are recorded, at least, from nine other localities (often included in the so-called Khazar, Tiraspol, and Tatar regional faunas). Four of them are located in the European Russia:

1) Kurilovka along the Bol'shoy Uzen' River (Saratov Province) (Belyaeva, 1935; Gromova, 1935);

2) Right bank of the Volga River between the villages Cherny Yar and Nizhnee Zaimishche (Astrakhan' Province) (Gromova, 1932, 1935). Both localities are referable to the Likhvin horizon according to the Eastern-European stratigraphic nomenclature, Tobol' horizon in the Siberian nomenclature, or Holstein in the Western-European nomenclature;

3) Samara (Samara Province) (Strizheva, 1991);

4) Podosinik (Volgograd Province) (unpublished material). Both last localities have no stratigraphical data.

Remains of $S$. kirchbergensis have also been discovered in five other localities in Siberia:

1) Along the Ob' River near the Krasny Yar village (Krivosheino District, Tomsk Province) (Alekseeva, 1980), without stratigraphical data;

2) Along the right bank of the Ob' River at Krasny Yar, in front of the Sargulin Island (Krivosheino District, Tomsk Province) (Billia \& Shpansky, 2005), in the Tobol' horizon level, together with remains of Mammuthus ex gr. trogontherii-chosaricus, Bison priscus Bojanus, 1827, and Equus ex gr. mosbachensis-germanicus; 
3) Along the right bank of the Inya River, $58 \mathrm{~km}$ south-west of Kemerovo (Kuznetsk Basin, Kemerovo Province) (Billia, 2005a, in press a-c), without accompanying fauna and stratigraphical data;

4) Mokhovo, about $20 \mathrm{~km}$ east of Leninsk-Kuznetsky (Kuznetsk Basin, Kemerovo Province) (Billia, 2005a, in press a-c), in the Shirtinsk horizon level on the Western-Siberian stratigraphy, Odinzov horizon in the Eastern-European stratigraphy, or Holstein in the Western-European stratigraphy. Found together with a great number of fossils ascribed to Panthera spelaea (Goldfuss, 1810), Cervus elaphus L., 1758, Megaloceros giganteus (Blumenbach, 1803), Bison priscus Bojanus,1827, Rangifer tarandus L., 1758, Equus sp., Ursus cf. U. arctos L., 1758, Mammuthus cf. M. intermedius (Jourdan, 1861), a transitional form with morphological characters between $M$. chosaricus Dubrovo, 1966 and primitive forms of M. primigenius (Blumenbach, 1799). All these taxa are included in the so-called Tatar Fauna (Foronova, 2001);

5) Along the left bank of the Vilyui River, close to its confluence with the Chebydy River, between the villages of Verkhne-Vilyuisk and Vilyuisk (Republic Yakutiya) (Dubrovo, 1957), probably in the Shaytansk horizon level on the Western-Siberian stratigraphy, Oka horizon in the Eastern-European stratigraphy, or Elster in the Western-European stratigraphy. Found together with a fragmentary molar of Archidiskodon trogontherii Pohlig, 1885. The remains may be referred to the Tiraspol' faunistic complex. This is the northernmost record for $S$. kirchbergensis (about $64^{\circ} \mathrm{N}$ latitude).

In the literature (Gromova, 1932, 1935; Belyaeva, 1935, 1939, 1940), some other Russian European localities which would yield remains ascribed to $S$. kirchbergensis are also mentioned, but unfortunately the material is not traceable at present (Billia, in press a-c).

The teeth and postcranial bones of $S$. kirchbergensis, found along the right bank of Dnepr River near Vysokoe, about $15 \mathrm{~km}$ south-east of Smolensk (Smolensk Province) and housed in the Zoological Museum of the Smolensk State University (ZMSU), has been lost during the German occupation in the 1941 (Salov, 1957).

In the territory of the former Soviet Union, remains of S. kirchbergensis are positively identified from Koshkurgan in Alma-Ata Province, southern Kazakhstan (Khisarova, 1963). Some other remains possible referable to the same species would come from other localities of Kazakhstan (Kozhamkulova, 1981; Kozhamkulova \& Kostenko, 1984; Tleuberdina et al., 1990), from two localities of Tajikistan (Dmitrieva \& Nesmeyanov, 1982), from Azerbaijan (Aliev, 1969), and from Kolkotova balka in Moldova, Tiraspol' area (David, 1980).

In any case, the rarity of this species - despite of its being widely spread in Eurasia - has been witnessed on Russian territory (Billia, 2005a, in press a-c) as well as in the Western European area (Billia, 2005b). The reasons of this rarity have not been unraveled yet; according to Loose (1975), it may probably be due to two reasons: its ecological niche was unfavorable for its fossilisation or it was really a rare animal. I incline to the second hypothesis.

The problem concerning the phylogenetic relationship between $S$. kirchbergensis and other ancestral rhinoceros species is still unresolved. With $S$. megarhinus (de Christol, 1834), possible belonging to the same clade, being confined to the early Pliocene, a wide temporal hiatus is placed between it and S. kirchbergensis.

ACKNOWLEDGMENTS. I am very much indebted to Aleksandr O. Averianov and to Aleksey N. Tikhonov (Zoological Institute, Russian Academy of Science, St. Petersburg) for having placed the kirchbergensis skull and other kirchbergensis material at my disposal. I also wish to thank very much Nina V. Garutt (Institute of Mines, St. Petersburg) for her valuable comments and suggestions. My long stay in Russia has partly been financed by NATO.

\section{References}

Alekseeva E.V. 1980. [Pleistocene Mammals of South-East of Western Siberia. Carnivores, Proboscidians, Ungulates]. Moskva: Nauka. 187 p. [in Russian].

Aliev S.D. 1969. [The Fauna of the Paleolithic Site of Azych]. Baku: Izdatel'stvo AN Azerbaidzhanskoi SSR. 30 p. [in Russian].

Azzaroli A. 1962a. Rinoceronti pliocenici del Valdarno Inferiore // Palaeontographia Italica. Vol.57 (Nuova Serie, Vol.27). P.11-20.

Azzaroli A. 1962b. Validità della specie Rhinoceros hemitoechus Falconer // Palaeontographia Italica. Vol.57 (Nuova Serie, Vol.27). P.21-34.

Bar-Yossef O. \& Chernov E. 1972. On the Palaeo-Ecological History of the Site of 'Ubeidiya. Jerusalem: Israel Academy of Sciences and Humanities. 35 p.

Belyaeva E.I. 1935. [Some data on the Quaternary mammals from the area of the lower Volga River based on the materials in the Pugachev city Museum] // Trudy Komissii po Izucheniyu Chetvertichnogo Perioda. No.4. Vyp.2. P.303-308 [in Russian with German summary].

Belyaeva E.I. 1939. [On fossil rhinoceros remains from the environs of Rybinsk city] // Trudy Komissii po Izucheniyu Chetvertichnogo Perioda. No.5. P. 69-90 [in Russian].

Belyaeva E.I. 1940. [New finds of Merck's rhinoceros remains in the territory of the Soviet Union] // Priroda. No.8. P.82 [in Russian].

Bernsen J.J.A. 1927. The geology of the Tegelian Clay and its fossil remains of Rhinoceros. Thesis University Amsterdam. 108 p.

Billia E.M.E. 2005a. Records of Stephanorhinus kirchbergensis (Jaeger, 1839) (Mammalia, Rhinocerotidae) from South-East of Western Siberia: a rareness of a species // Ecosystems of Mongolia and Frontier Areas of Adjacent Countries: Natural Resources, Biodiversity and Ecological Prospects. Proceedings of the International Conference. Ulaanbaatar. 2005. P.57-58.

Billia E.M.E. 2005b. Odontological distinguishing characters of Stephanorhinus kirchbergensis (Jaeger, 1839) (Mammalia, Rhinocerotidae) with a revision of the spe- 
cies in Italy // [Evolution of Life on the Earth. Proceedings of the Third International Symposium]. Tomsk: Izdatel'stvo Tomskogo Gosudarstvennogo Universiteta. P.321-325.

Billia E.M.E. in press a. First records of Stephanorhinus kirchbergensis (Jäger, 1839) (Mammalia, Rhinocerotidae) from the Kuznetsk Basin (Kemerovo region, Kuzbass area, South-East of Western Siberia) // Bollettino della Società Paleontologica Italiana.

Billia E.M.E. in press b. Revision of the fossil odontological material attributed to Stephanorhinus kirchbergensis (Jäger, 1839) (Mammalia, Rhinocerotidae) preserved in the museum collections of the Russian Federation // Stratigraphy, Palaeontology, and Palaeoenvironment of Pliocene-Pleistocene of Transbaikalia and Interregional Correlations. Proceedings of INQUA International Symposium. Ulan-Ude.

Billia E.M.E. in press c. Catalogue of the Odonto-osteological Material Attributed to Stephanorhinus kirchbergensis (Jaeger, 1839) (Mammalia, Rhinocerotidae) Preserved in the Museum Collections of the Russian Federation (with a Bibliographic List on the Rhinocerotidae Family with over than 1200 References). NATO-CNR Outreach Fellowships Research Thesis. 149 p.

Billia E.M.E. \& Petronio C. in press. Records of Stephanorhinus kirchbergensis (Jäger, 1839) (Mammalia, Rhinocerotidae) from Italy // Bolletino della Società Paleontologica Italiana.

BilliaE.M.E. \& Shpansky A.V. 2005. Stephanorhinus kirchbergensis (Jäger, 1839) (Mammalia, Rhinocerotidae) from the Middle Pleistocene levels of the Ob' River at Krasny Yar (Tomsk region, Western Siberia) // Deinsea. Vol.11. P.75-82.

Borsuk-Bialyńicka M. \& Jakubowski G. 1972. The skull of Dicerorhinus mercki (Jäger) from Warsaw // Prace Muzeum Ziemi. Vol.20. P.187-199.

Brandt J.F. 1877. Versuch einer Monographie der Tichorhinen Nashörner nebst Bemerkungen über Rhinoceros leptorhinus Cuvier // Zapiski Imperatorskoi Akademii Nauk, Seriya 7. T.24. No.4. P. 1-135.

Chersky I.D. 1874. [Description of a rhinoceros skull different from Rhinoceros tichorhinus] // Zapiski Imperatorskoi Akademii Nauk, Seriya 5. T.25. No.2. P.65-75 [in Russian].

Czyżewska T. 1962. Uzebienie górnej szczeki Dicerorhinus mercki (Jager) ze Szczęśliwic kolo Warszawy // Acta Paleontologica Polonica. Vol.7. No.1-2. P.223-234.

David A.I. 1980. [Theriofauna of the Pleistocene of Moldavia]. Kishinev: Shtiinza. 186 p. [in Russian].

Dmitrieva E.L. \& Nesmeyanov S.A. 1982. [Mammals and stratigraphy of continental Tertiary deposits of southeast of Middle Asia] // Trudy Paleontologicheskogo Instituta. T.193. P.1-140 [in Russian].

Dubrovo I.A. 1957. [On remains of Parelephas wuesti (M. Pavl.) and Rhinoceros mercki Jaeger from Jakutiya] // Byulleten' Komissii po Izucheniyu Chetvertichnogo Perioda. No.21. P.97-104 [in Russian].

Flerov K.K., Trofimov B.A. \& Yanoskaya N.M. 1955. [History of mammal fauna in the Quaternary Period]. Moskva: Izdatel'stvo MGU. 39 p. [in Russian].
Foronova I.V. 2001. [Quaternary Mammals of South-East of Western Siberia (Kuznetsk Basin). Phylogeny, Biostratigraphy, and Paleoecology]. Novosibirsk: Izdatel'stvo SO RAN. 243 p. [in Russian].

Fortelius M., Mazza P. \& Sala B. 1993. Stephanorinus (Mammalian, Rhinocerontidae) of the western European Pleistocene, with a revision of $S$. etruscus (Falconer, 1868) // Palaeontographia Italica. Vol.80. P.63-155.

Freudenberg W. 1914. Die Säugetiere des altern Quartärs von Mitteleuropa mit besonderes Berücksichtigung der Faunen von Hundsheim und Deutsch-Altenburg in Niederösterreich nebst Bemerkungen über verwandte Formen anderer Fundorte // Geologische und Paläontologische Abhandlungen, Neue Folge. Bd.12. Hf.4-5. S.455-671.

Fu Z. 2002. [Quaternary mammal fauna of Dunbey Pleistocene and its specificity] // Arkheologya, Etnografiya i Antropologiya Evrazii. T.1. No.9. P.6-15 [in Russian].

Gorjanovich-Kramberger D. 1913. Fossilni rinocerotidi Hrvatske i Slavonije, s osobitim obzirom na Rhinoceros mercki iz Krapine (De rhinocerotidibus fossilibus Croatie et Slavoniae, praecipua ratione habita Rhinocerotis mercki var. Krapinensis mihi) // Djela Jugoslavica Akademia. Vol.22. No.8. P.1-96.

Gromova V.I. 1932. [New materials on Quaternary fauna of the Volga River region and history of mammals of the Eastern Europe in general] // Trudy Komissii po Izucheniyu Chetvertichnogo Perioda. No.2. P.69-184 [in Russian].

Gromova V.I. 1935. [On remains of Merck's rhinoceros (Rhinoceros mercki Jaeg.) from lower Volga River region] // Trudy Paleontologicheskogo Instituta AN SSSR. T.4. P.91-131 [in Russian with German abstract].

Guérin C. 1980. Les Rhinocéros (Mammalia, Perissodactyla) du Miocène terminal au Pléistocène supérieur en Europe occidentale. Comparaison avec les espèces actuelles. Thèse Doctorat d'Etat et Sciences, Universite Lyon I // Documents des Laboratoires de Géologie de Lyon. T.79. No.1-3. P.1-1185.

Heissig K. 1981. Probleme bei der cladistichen Analyse einer Gruppe mit wenigen eindeutigen Apomorphien: Rhinocerotidae // Paläontologische Zeitschrift. Bd.55. Hf.1. S.117-123.

Hooijer D.A. 1961. The fossil vertebrates of Ksar' Akil, a Palaeolithic rock shelter in the Lebanon // Zoologische Verhandelingen. No.49. P.3-68.

Jaeger G.F. 1835-1839. Über die fossilen Säugetiere welche in Würtemberg in verschiedenen Formationen aufgefunden worden sind, nebst geognotischen Bemerkungen über diese Formationen. Stuttgart: C. Erhard Verlag.

Kahlke H.-D. 1977. Die Rhinocerotiden-Reste aus den Travertinen von Taubach bei Weimar // Quartärpaläontologie. Bd.2. S.305-359.

Kahlke H.-D. 1978. Die Rhinocerotiden-Reste aus den Travertinen von Burgtonna in Thüringen // Quartärpaläontologie. Bd.3. S.129-135.

Kahlke H.-D. 1984. Die Rhinocerotiden-Reste aus den Travertinen von Weimar (Travertine im Stadtgebiet) // Quartärpaläontologie. Bd.5. S.381-387.

Khisarova G.D. 1963. [Fossil bones of mammals from Koshkurgan gryphon (Southern Kazakhstan)] // Materialy po 
istorii fauny i flory Kazakhstana. No.4. P.42-50 [in Russian].

Kozhamkulova B.S. 1981. [Late Cenozoic Ungulates of Kazakhstan]. Alma-Ata: Izdatel'stvo AN Kazakhskoi SSR. 144 p. [in Russian].

Kozhamkulova B.S. \& Kostenko N.N. 1984. [Extinct animals of Kazakhstan (Paleogeography of the Late Cenozoic)]. Alma-Ata: Izdatel'stvo AN Kazakhskoi SSR. 103 p. [in Russian].

Kretzoi M. 1942. Präokkupierte und durch ältere zu ersetzende Säugetiernamen // Földtani Közlöny. Vol.72. No.4-12. S.345-349.

Kurtén B. 1968. Pleistocene Mammals of Europe. London: Weidenfeld \& Nicolson. 317 p.

Lartet E. 1867. Notes sur deux têtes de Carnassiers fossiles (Ursus et Felis) et sur quelques débris de Rhinocéros provenant des découvertes faites par M. Bourguignat dans les cavernes du Midi de la France // Annales de Sciences Naturales (Zoologie). T.5. No.8. P.157-194.

Lee Y.-J. 2001. Bone remains from Sae-kul and Cheonyokul of the Turubong Cave Complex in Korea // Asia and the Middle Pleistocene in Global Perspective. Proceedings of the International Scientific Conference. Honolulu: Honolulu State University Publishing House. Vol.3. P.14-17.

Loose H.K. 1975. Pleistocene Rhinocerotidae of Western Europe with Reference to the Recent two-horned species of Africa and S.E. Asia // Scripta Geologica. No.33. P.159.

Mayer G. 1971. Beiträge zur Geschichte der Badischen Landessammlungen für Naturkunde in Karlsruhe. Der Schädel des Dicerorhinus mercki (kirchbergensis) (Jäger) var. brachycephalus Schroeder von Daxlanden und seine Geschichte // Beiträge zur naturkunde Forschungsberichte Südwestfalen. Bd.30. Hf.2. S.157-163.

Meyer H.v. 1863-1864. Die diluvianen Rhinoceros-Arten // Palaeontographica. Bd.11. S.233-283.

Salov I.N. 1957. [Finds of fossil Quaternary fauna in the Smolensk region] // Smolenskii Oblastnoi Kraevedcheskii Muzei. T.2. P.311-333 [in Russian].

Schroeder H. 1903. Die Wirbelthier-Fauna des Mosbacher Sandes, 1. Gattung Rhinoceros // Abhandlungen der Königliche Preußischen geologische Landesanst, Neue Folge. Bd.18. S.1-143.

Schroeder H. 1905. Rhinoceros mercki Jäger von Heggen im Sauerlande // Jahrbuch der Königliche Preußischen geologische Landesanst. Bd.26. Hf.2. S.212-239.

Schroeder H. 1930. Über Rhinoceros mercki und seine nord- und mitteldeutschen Fundstellen // Abhandlungen der Preußischen geologische Landesanst, Neue Folge. Bd.124. S.1-114.

Staesche K. 1941. Nashörner der Gattung Dicerorhinus aus dem Diluvium Württembergs // Abhandlungen der Preußischen Geologischen Landesanstalt. Hf.200. S.1148.

Strizheva I.M. 1991. [Osteological remains of large mammals from the Samara Luka district] // Samarskaya Luka. T.2. P.197-205 [in Russian].

Teilhard de Chardin P. \& Pei W.C. 1941. The fossil Mammals of locality 13 in Choukoutien // Palaeontologia Sinica, Series C. Vol.11. No.4. P.1-105.

Tleuberdina P.A., Kozhamkulova B.S. \& Kondratenko G.S. 1990. [Catalogue of the Cenozoic Mammals of Kazakhstan]. Alma-Ata: Izdatel'stvo AN Kazakhskoi SSR. 135 p. [in Russian].

Toula F. 1907. Rhinoceros mercki Jäger in Österreich // Jahrbuch der Kaiserlich-Königliche geologische Reichsanstalt. Bd.57. Hf.3. S.445-454.

Wang T. 1961. The occurrence of Stegodon and Merck's rhinoceros near Taiyuan, Shansi // Vertebrata PalAsiatica. Vol.6. No.2. P.160-162.

West R.G., Lambert C.A. \& Sparks B.W. 1964. Interglacial deposits at Ilford (Essex) // Philosophical Transactions of the Royal Society of London, Series B. No.738, 247. P.185-212.

Woodward H.M. 1874. On the remains of Rhinoceros leptorhinus Owen ( $R$. hemitoechus Falc.) in the collection of Sir Antonio Brady, FGS, from the Pleistocene Deposits of the Valley of the Thames at Ilford (Essex) // Geological Magazine. Vol.11. P.398-403.

Wüst E. 1901. Untersuchungen ueber das Pliozaen und das aelteste Pleistozaen Thueringens, noerdlich vom Thueringerwalde und westlich von der Saale // Abhandlungen der. Naturforschenden Gesellschaft. Bd.23. S.21-368.

Wüst E. 1909. Das Vorkommen von Rhinoceros merckii Jäger in den oberen Travertinen von Ehringsdorf bei Weimar und seine Bedeutung für die Beurteilung der Klimaschwankungen das Eiszeitalters // Centralblatt für Mineralogie, Geologie und Paläontologie. Jg.1909. S.23-25.

Wüst E. 1922. Beiträge zur Kenntnis der diluvianen Nashörner Europas // Centralblatt für Mineralogie, Geologie und Paläontologie. Bd.20. S.641-656; Bd.21. S.680-688.

Xu X. 1986. Dicerorhinus kirchbergensis (Jäger, 1839) from the late Middle Pleistocene mammalian fauna of Anping (Liaoning) // Vertebrata PalAsiatica. Vol.24. No.3. P.229241. 